\title{
COMBATING CLIMATE CHANGE IN CAMBODIA: GREENWASHING OR REALITY?
}

\author{
Oluwadamilola Titilope OSEKITA \\ Vytautas Magnus University, Kaunas, Lithuania \\ (ddosekita@gmail.com) \\ DOI: https://doi.org/10.22452/jati.vol25no1.6
}

\begin{abstract}
From wildfires in Bolivia, floods, and mudslides in South Africa, Nepal, and Myanmar, to heatwaves in Australia and Europe, the impact of climate change is felt globally but in unequal measures, as developing and least developed countries suffer the most devastating impacts despite being the least contributors. As a result, climate change is center stage because countries and their governments, organisations as well as multinationals are battling to contain its effects. Through the Nationally Determined Contributions of the Paris Agreement, countries pledged to mitigate climate change in their capacities. However, some of these contributions are overly ambitious for poor countries like Cambodia measuring it against their national capacities. Therefore, this paper investigates Cambodia's official position on climate change vis-à-vis its current environmental practices, mitigation policies, and strategies by analysing three major climate change amplifiers - waste, deforestation and greenhouse gas emissions to determine whether it is the environmentally friendly country it portrays itself to be internationally or simply greenwashing. This paper merges both qualitative content and document analyses of official policy documents and agreements, reports, data, and publications of major climate change stakeholders in Cambodia. By in-depth analysis, it is established that Cambodia shows commitment to combating climate change, however, with current environmental practices and policy implementation, Cambodia moves towards solving the pressing issues of hunger and poverty with economic growth and development as a priority before consideration for the climate and environment. On this basis, it is recommended that the least developed countries set and maintain realistic climate goals and continue to receive external support from developed countries with monitoring and evaluating systems established to be up to par in the fulfilment of global agendas such as Agenda 2030.
\end{abstract}

Keywords: greenwashing, climate change, El Niño, climate action, Cambodia, climate justice 


\section{Introduction}

Cambodia is a South-East Asian rural country about three times the size of Lithuania and only about a quarter of France. To its West and North-West is Thailand, to its North-East is Laos, to its Southwest is the Gulf of Thailand, and to its East and South-East is Vietnam. Cambodia is characterised by mountains as well as the Tonle Sap, which is the largest lake in South-East Asia and the Mekong River that cuts across other countries. It also has several plains and a tropical climate. The terrain in Cambodia is three types - the coastal areas are to its southwest where most palm oil production, fishing, and water-related activities are carried out. The second area to the north and northeast is made up of mostly mountains and plateaus, and some mangrove forests. The third area which is across the middle of the country where the Tonle Sap Lake passes through is where most rice farmers cultivate their crops because of the flatness of the ground and the swamps. Cambodia has 25 provinces (Population Reference Bureau for Cambodia, n.d.) altogether and none is exempt from climate change problems. Cambodia has experienced a series of natural disasters alongside its Asian counterparts like Myanmar, Malaysia, Thailand, Vietnam, Laos, Indonesia, and the Philippines.

In Cambodia, droughts and floods are annual occurrences that have had devastating effects on the country. For instance, in 2013, there were too many rains in the rainy season that caused the Mekong River to overflow and led to typhoons and heavy flooding, about 3 months later, about 1.8 million people had been badly affected across 20 provinces and caused the deaths of nearly 200 people (UNOCHA, 2014). Additionally, between 2015 and 2017, the 25 Cambodian provinces suffered shortages in water supply due to drought that engulfed many of its neighbours and was considered to be the worst in 50 years with about 625,000 Cambodian households badly affected by the droughts ("Asia and the Pacific", 2016).

The major sources of income are fishing and farming with the majority of the population dependent on these scarce sources for survival. Cambodia is listed as one of the poorest countries in the world, first because of its poor infrastructures and developmental issues. Also, its bad economy and geography make it more difficult. Concerning climate change issues, Cambodia is highly endangered and ranks 10 on a scale of 1-10, with 10 meaning 'high risk' in the Disaster Risk Index of 2017. The Disaster Risk Index states that 9.5 million of Cambodia's population is susceptible to floods, 4.4 million to tsunamis, and 3.9 million to cyclones (European Commission: Disaster Risk Management Knowledge Centre, 2018). However, the country has experienced major environmental and climate change issues such as floods and droughts due to 
human activities threatening natural habitats of plant and animal life and also humans (Borg, 2011). Despite Cambodia being party to various international environmental and climate change agreements such as the Kyoto Protocol and the Paris Agreement, this has not improved nor prevented the heavy consequences of illegal human activities as well as the global climate change issues affecting many countries and territories. Cambodia ranks as one of the poorest countries in the world and also one of the top ten countries that risks being annihilated by climate change impacts due to poor infrastructure, geography and projected population growth that will further burden the already compromising climatic conditions and scarce resources.

The paper provides answers to the following research questions - what are the ways in which Cambodia is combatting climate change? Is Cambodia taking the necessary steps to be an environmentally friendly country or just posing as one? What are Cambodia's achievements, if any, in climate change mitigation? What is the reality as regards to environmental practices in Cambodia? The goal of this paper is to examine Cambodia's environmental practices to determine whether it is a country that desires by its actions to be environmentally friendly or it is just simply "greenwashing". In other words, this paper analyses Cambodia's official position about climate change and investigates Cambodia's environmental practices, policies and programmes using the concept of greenwashing, blue washing and green public relations to see whether it shows commitment to climate change mitigation and adaptation strategies. This paper hopes to contribute to existing literature on climate change in Cambodia that examines climate change governance on the national and international partnership levels as well as the role that all actors play in adaptation and mitigation (Käkönen, Lebel, Karhunmaa, Dany, \& Try, 2014). Others examine climate change and LDCs in relation to adaptation, economic migration and participation in climate change networks (Cornell, 2010; Lilleør \& Van den Broeck, 2011; Huq et al., 2004). Analysing how Cambodia, one of the least developed countries, can align its economic development interests and priorities with global agreements on sustainable development that it has agreed to commit to. This is because it is common knowledge that countries that want to boost their economies find it difficult to adhere and achieve the sustainable development goals.

\section{Understanding the Concept of Greenwashing}

The term 'greenwashing' is traceable to an environmentalist, Jay Westerveld in the 1980s who observed hotels at the time encouraged their guests to reuse their towels as a way of 'saving' the environment and later discovered that reusing 
towels was not to save the environment at all but was a strategy used in cutting the cost of laundry (AZoCleantech, 2008). There is a growing trend of companies and countries portraying themselves in ads, campaigns, reports, sustainable development conferences, and conventions as being environmentally conscious since eco-friendly practices in agriculture, production, mining, manufacturing, refuse disposal, fishing and so on gained popularity (Rinkesh, n.d.). There is a growing trend for companies to portray themselves in ads, campaigns, reports, sustainable development conferences, and conventions as being environmentally conscious since eco-friendly practices in agriculture, production, mining, manufacturing, refuse disposal, fishing and so on gained popularity (Rinkesh, n.d.) The term 'greenwashing' is traceable to an environmentalist, Jay Westerveld in the 1980s who observed hotels at the time encouraging their guests to reuse their towels as a way of 'saving' the environment and later discovered that reusing towels was not to save the environment at all but was a strategy used in cutting the cost of laundry (AZoCleantech, 2008).

Environmental activists are constantly criticising many companies from Boeing to GlaxoSmithKline for greenwashing their activities; in other words, hoodwinking their clients and consumers about their climate credentials through the use of green public relations combined with horrible environmental practices that have left many industrialised areas prone to poor climatic conditions (Smith, 2017). For example, in autumn 2017, Greenpeace International, a nongovernmental organisation focused on worldwide issues such as climate change and how to sustain the earth, lambasted Amazon whose owner is one of the richest men in the world for their poor environmental practices (Fingas, 2017). Greenpeace is known for investigating and exposing companies who claim to be putting their environments into consideration while carrying out activities such as manufacturing, mining, and extraction, etc.

According to Greenpeace, companies are rated between ' $\mathrm{A}$ ' and ' $\mathrm{F}$ ' where $A$ is meant that a company's production of products and services made good on its promise to protect the environment such as the use of renewable energy sources, toxin-free materials and so on. On the other hand, companies that scored F utilised non-renewable energy sources and toxin-filled materials. In 2017, Amazon Inc. fell in the ' $F$ ' category because Greenpeace alleged that Amazon Inc. was being vague about its reports and discussions on its environmental practices. For instance, there was no data publication concerning the company's use of energy, the sort of materials they utilise, as well as limits on the use of dangerous materials. Greenpeace also claimed that Amazon Inc. made environmentally friendly policies but had not made strong commitments to reducing the impacts of its activities and products on the climate. However, this is not to accuse 
Amazon Inc. of not making any efforts to improve the planet, but if they are, it is simply not being reported (Bowen, 2018). Arguably, Amazon Inc. is not alone in this kind of practice; it is just one of many other businesses that make claims of protecting the environment but when investigated, these claims are found to be untrue (Forbes \& Jermier, 2012). This is what is referred to as greenwashing and also, green public relations that will be expatiated on in a different subchapter.

\section{Understanding the Concept of Blue-washing}

Discussions about blue washing cannot go on without mentioning the United Nations Global Compact, launched in 1999 which striked a deal with private companies and industries as a result of the failure of countries to adhere to, implement and monitor agreements on human and labor rights, etc. This initiative allowed companies to have a direct partnership with the United Nations on its ten principles that have climate change as one of the most important policy areas. This deal is to ensure companies, who are participants, conform to the principles to consider labor laws, human rights, and most importantly, to protect their environment. In exchange, these companies are allowed to call themselves partners of the United Nations and utilise the United Nations blue logo in their advertisements, publications, and reports. The UN Global Compact's mission is to "mobilise a global movement of sustainable companies and stakeholders to create the world we want" (United Nations Global Compact, 2000). The United Nations Global Compact agenda is made up of ten principal areas that the United Nations has to adhere to. The seventh, eighth and ninth areas of this agenda are mainly centered on the environment, encouraging Global Compact partners to adopt precautionary approaches to utilise mineral and natural resources as well as choose bio-friendly options for their activities. There are several controversies surrounding companies that are in the UN Global Compact. First, there are no binding measures that the companies need to follow except to submit an annual report which is not verified or evaluated, even though the Global Compact suspend companies that fail to submit their annual reports. Secondly, most non-governmental organisations say that these companies have only been using the UN partnership as a leverage to continue to exploit the environment in negative ways, not adhering to the standards set out by the partnership, which in climate change terms, is referred to as 'blue washing' (Rampton, 2002).

Blue washing is not far a term from greenwashing; in fact, many believe that blue washing is the new and improved greenwashing (Greenwash Fact Sheet, 2001). The term 'blue' refers to the United Nations' logo and overall. Blue washing as a term is used to condemn the UN Global Compact partnerships with 
corporations that are believed to use the UN partnership as a means to boost their reputations, even though, in practice, they are constantly violating the laid down principles of the Global Compact partnerships including the upsetting of the ecosystem, climate, and environment as all they look forward to is profit (Zumach, 2011).

The New York Times describes blue washing as "allowing some of the largest and richest corporations to wrap themselves in the United Nations' blue flag without requiring them to do anything new" (Schott, 2010). In the Cambodian context, only three of the companies in the country are partners with the UN Global Compact, and they are Cambodian Mango Farms Ltd., Knai Bang Chatt Resort and Ezecom. The companies and corporations operational in Cambodia range from agricultural to construction. Therefore, it is unclear how these other companies are monitored. According to the technical assessment report carried out by the Cambodian government in collaboration with some NGOs in 2017, agricultural expansion and over-exploitation of forest reserves, illegal logging, and illegal wildlife trading as well as a lack of financial and technical resources for the populace and sewage disposal and management are some of the major causes of the climate change issues in Cambodia. Other collaborations are with the United Nations Framework Convention on Climate Change (UNFCCC), under the REDD+ platform for developing countries in which Cambodia, where a participant is expected to reduce the emission of greenhouse gases as a result of deforestation and degradation (Solid Waste Management App, 2018).

\section{Green Public Relations in Cambodia}

In recent history, the term 'green' became rampant in most spheres, from food production to garment making, companies, corporations and government institutions soon realised that the need to be environmentally friendly was becoming a norm, and if done properly, it will translate to more revenue or profit. The resultant effect of this is the race for finished lines without going through the process of being green; these organisations by their ads, reports, and so on forge facts to make it seem like they are responsible 'climate-wise'. The attempt at portraying oneself as being environmentally responsible is known as green public relations. Green public relations refer to communication or noncommunication of environmental practices (United Nations Global Compact, n.d.). As a general rule, for instance, a country cannot be engaging in bad environmental practices and put it on the news or in their advertisements or reports. It is either they stay quiet about it or cover those aspects of their practices that may have green or eco-friendly parts. This way, bad practices are 
depicted in a positive light while good practices also receive the same kind of publicity. Why do countries or companies engage in green PR? The answer is simple, gaining a reputation both nationally and internationally. For instance, a country like Finland according to the Environmental Performance Index ranks first out of 180 (Oliver, 2017; Environmental Performance Index, 2018b) countries as being the most environmentally friendly in the world, followed closely by Iceland and Sweden. This practice has earned Finland a reputation and also serves as a model for countries striving to be better to emulate by making use of renewable energy sources, other best practices as well as structures put in place to ensure a green and better environment for all.

Green public relations can, therefore, be defined as the need to forge and sustain a pragmatic image regarding matters involving one's environment and climate using the media and other forms of communication to portray this pragmatic image to the general public. For instance, in Cambodia, there is the Department of Climate Change which is the main government agency saddled with the responsibility of all climate and environmental activities. The agency also represents Cambodia both regionally and internationally with issues of climate change. In order to effectively carry out its functions, the Department of Climate Change is subdivided into five other departments. The department responsible for Green Public Relations under the DCC is the Office of Information Management whose primary role is to "design, develop and manage climate change information and knowledge management system; Disseminate government response to climate change to the public, development partners and international community"(General Secretariat of the National Council for Sustainable Development, 2014). Additionally, the Cambodian Office of Information Management also makes decisions about what is published or broadcasted and serves as the Cambodian Government's overall Public Relations Office. Cambodia's green public relations is how Cambodia tells their story about their environmental and climatic conditions; some of these ways will be explored when analysing Cambodia's real position about combating the issue of climate change.

\section{Cambodia's Position and Practices on Climate Change}

This section zooms in on Cambodia's official position on climate change regionally and globally against its climate change policies and environmental practices such as waste disposal and management, methods of pollution reduction, mining and extractive activities, agricultural methods, exploitation of water and land resources, conservation, etc. as a result of its policies and programmes and to see whether or not, these practices have a positive or 
negative impact on the climate.

Due to human activity, waste is generated daily, therefore, indispensable (Rathana, 2009). Not knowing how to dispose of these waste materials becomes a problem for the environment and human health as well. Waste management and disposal differ from one place to the other, but the methods used in management and disposal are what is important. Some waste materials are collected, recycled, and reused, while some are dumped in heaps, in water bodies, or on empty lands to decay, burned, or left to get washed off into drainages and other water channels.

Waste management and pollution are not mentioned when analysing Cambodia's climate change policies and reports to both regional and international bodies. Most of the reports and policies are mainly focused on carbon emissions, forest cover and so on without paying attention to the issue of waste disposal that can be seen on the roads and streets in its cities. If the government must reduce its greenhouse gas emissions, for instance, it should also work tirelessly on proper waste disposal and management. Some private individuals and organisations like Go Green Cambodia have launched apps and campaigns with government support via the Ministry of Environment. The Cambodian government has said it has organised several campaigns highlighting the consequences of a dirty environment (Tola, 2018). The Cambodian government as part of its regional cooperation under ASEAN endorsed the ASEAN Clean Tourist City Standards in 2011 and was awarded this year for three of its cities for being one of the cleanest among the ASEAN cities. The cities are Kep, Battambang, and Siem Reap (Chan, 2018) which are Cambodia's most touristic cities. They were awarded because of their cleanliness and reduced water and air pollution compared to twenty-three other ASEAN cities (Overland, 2017).

\section{Waste Management and Pollution in Cambodia}

According to the Environmental Performance Index of 2018, Cambodia ranks 150 out of 180 countries compared to the $146^{\text {th }}$ place it ranked in 2016. Cambodia is followed by the Solomon Islands, Iraq, and Laos in the $151^{\text {st }}, 152^{\text {nd }}$ and $153^{\text {rd }}$ places respectively. Cambodia's Environmental Index Performance scorecard put Cambodia in the $152^{\text {nd }}$ position in environmental health, $164^{\text {th }}$ in air quality, $103^{\text {rd }}$ in climate and energy, $117^{\text {th }}$ in water and sanitation, etc. as seen in figure 1 below (Environmental Performance Index, 2018a). 


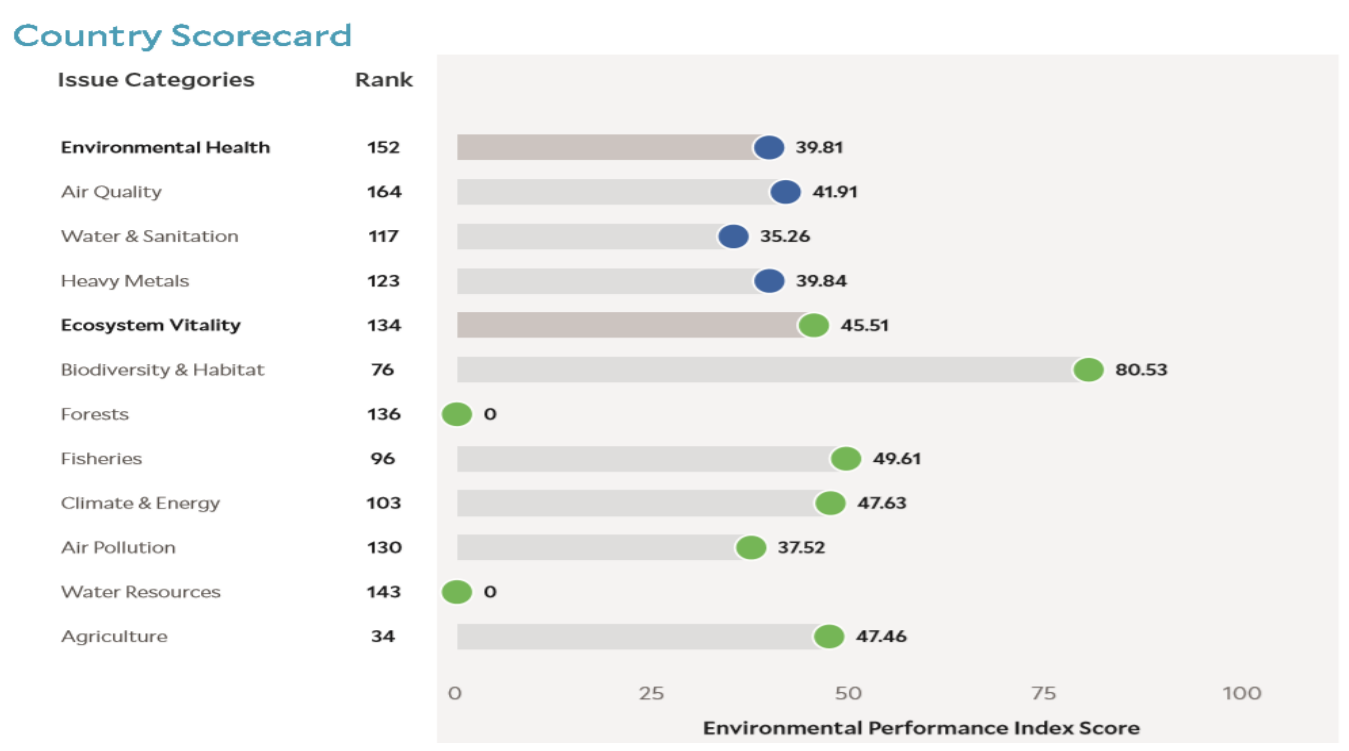

Figure 1: Cambodia's 2018 Environmental Performance Index Scorecard (Source: Environmental Performance Index [2018a].)

The population and economic growth in Cambodia over the last few years have had certain consequences on its climate and environment. One of the major consequences of this is waste and pollution, especially solid waste and the pollution of its air, water, and land ("Pollution and waste", 2016).

According to many news outlets and reports on waste management in Cambodia, the problem of waste disposal has been at the front burner for the last four to five years, although most of the news is focused on Phnom Penh, the country's capital (Sassoon \& Channyda, 2018). However, what happens in the capital mirrors the findings in the rural areas and other provinces. During the rainy seasons, the problem worsens due to improper waste disposal methods, an issue blamed on the growing population. With the rapidly growing population in Cambodia's 25 provinces (Population Reference Bureau Data Center, n.d.), more waste is churned out from markets, businesses, households, and restaurants.

The reports by the Asian Foundation and the Overseas Development Institute states that the problem with waste management is two-pronged, namely the amount of waste produced as well as the method of collecting and disposing of them ("The problem with landfill", 2013). The Cambodian government chose to landfill as its main method of disposing of waste across the country and Dangkao land allocated for this purpose in Phnom Penh, for instance, was projected to last 25 years but about five years into its use, between 2009 and 2014, 
about half of the land had been filled already and environmental experts further projected the land to last another five years until 2019 (Sopheap, Inatsu, Thavrak, \& Borarin, 2016). Investigations showed that the Cambodian government signed a 50-year contract plan with CINTRI Cambodia Ltd., a private waste management company to take charge of waste collection, management, and disposal. In turn, the citizenry pays a fee that is included in their electricity bills. But what we see is that payment does not translate to service as the streets, roads and drainages are dumping grounds for waste from households, offices, businesses, markets, and restaurants (Matussek \& Behrmann, 2018). The CINTRI Company subcontracted this contract to PSBK, another private company and the terms of the contract with the Cambodian government remain confidential, although the Ministry of Environment is saddled with monitoring and evaluation. Figure 2 is a photo of the Dangkao land allocated for landfilling.

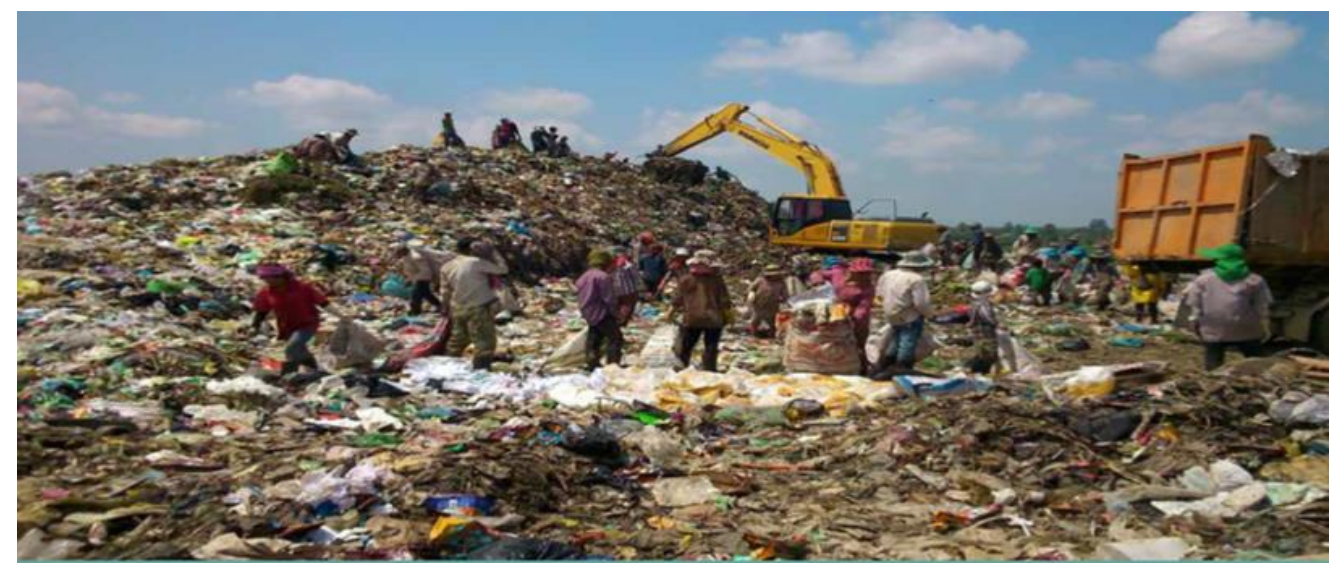

Figure 2: Dangkao Landfill in Phnom Penh (2014) (Source: The Asia Foundation, 2016)

This method of waste management is a far cry from what Cambodia portrays because landfilling is a poor way of getting rid of waste. The adverse effects of landfilling as seen in the picture above is not just an eyesore but when these wastes breakdown, they release heavy toxins into water bodies, affecting marine life such as fishes. Also, these toxins are absorbed into the soil and ground affecting plants, animals, and humans in the long run. Most of these waste products contain heavy metals like lead, mercury, and leachate. These practices, from waste management to deforestation are closely linked to climate change. When waste is dumped on landfills, they are burned or incinerated, releasing harmful gases such as nitrogen, methane, and carbon dioxide in excess into the atmosphere. Also with deforestation, trees that are supposed to absorb carbon 
dioxide are felled for economic purposes. Based on research findings, Cambodia ranked the highest annually in the acceleration of loss of forest cover from 2001 of about $14.4 \%$ to about $70 \%$ in 2016 according to the World Resources Institute (Petersen, Sizer, Hansen, Potapov, \& Thau, 2018). Information on Cambodia's waste management strategies or policies cannot be found in official government documents, but can only be found through media publications and on websites of external bodies on climate and environment. This lack of official information can be concluded to mean that Cambodia utilises green public relations since it means withholding information or failing to report or address issues related to the environment and climate. As a resultant effect of green PR, some of Cambodia's media houses have been shut down or had their licenses revoked. Information concerning this is found in the reports and websites of nongovernmental and environmental bodies like Open Development Cambodia.

\section{Cambodia's Position on Deforestation}

Deforestation is a major contributor to climate change issues as discussed in previous researches (Lawrence \& Vandecar, 2015; Tinker, Ingram, \& Struwe, 1996; Shukla, Nobre, \& Sellers, 1990; Moutinho \& Schwartzman, 2005). In Cambodia, tree forests are being converted for economic purposes especially for rubber plantations as world prices are increasing. Some experts in this area have made a correlation between tree felling and the demand for rubber in Cambodia (Erickson-Davis, 2017). In Cambodia's determination to maintain its forest cover and combat climate change according to regional and international policies from ASEAN and the United Nations, it has formulated several climate change policies such as the Cambodia Climate Change Strategic Plan to be implemented between the year 2014 and 2023, the National Policy on Green Growth and the National Strategic Plan on Green Growth from year 2013 to 2030 , (Policies and Plans, 2013) and most importantly, the National Forest Program. The Cambodian government appointed some ministries and agencies to oversee the implementation, monitoring, and evaluation of these policies in conjunction with other climate and environmental stakeholders.

However, Cambodia reports to the UNFCCC under the REDD+ umbrella that they have already been implementing the monitoring of their forests, based on four types - Deciduous forests, evergreen forests, semi-evergreen forests and a fourth one that was unnamed ("REDD+ Cambodia submissions", n.d.). Cambodia's most recent REDD+ report in August 2018 stated that the monitoring of its forest over the past four years was carried out by three agencies - the Forestry Administration, Fisheries Administration and the Ministry of Environment (National Forest Monitoring of Cambodia, 2015). These three 
agencies were expected to submit monthly, quarterly and annually reports in partnership with local offices located in all 25 provinces, while illegal tree felling and logging activities were reported to the central offices of the three agencies.

The National Forest Program is dedicated to forest resource management by the Cambodian government. The vision of this forest policy states that "the Royal Government of Cambodia considers the ecologically, socially and economically viable conservation and management of forest resources as a major pillar of public welfare directly contributing to environmental protection, poverty reduction, and socio-economic development" (National Forest Monitoring of Cambodia, 2015). The National Forest Policy defines the forest as "the unit of the natural ecosystem or plantation in form of wetland, lowland, and dryland which covers by natural stands of plantation trees with a height from 5 meters on the area of at least 0.5 hectares with a canopy of more than $10 \%$. The plantations such as rubber, oil palm, teak, acacia and eucalyptus and other kinds of trees which fall under the above criteria will also be classified as forests" (Cambodia Ministry of Environment, 2018). Essentially, to understand these specifications of what a forest should be, a sports field, for instance, is about one hectare, so half a sports field should be the size or area to be considered a forest, going by the above definition, while, a $5 \mathrm{~m}$ tree is equivalent to about 16 feet or about 196 inches in measurement. There is an issue with this definition because this means that trees and areas falling even slightly below these requirements cannot be considered a forest area and so can be felled or logged. To implement the REDD+ requirements, Cambodia restructured the above definition of forest according to the National Forest Policy as follows - "Forest under the REDD+ program refer to the unit of the ecosystem in form of wetland and dryland covered by natural or planted vegetation which area cover at least 0.5 hectares, height from 5 meters and canopy crown cover of more than 10\%" (Cambodia Ministry of Environment, 2018).

\section{Deforestation Practices in Cambodia}

From the above, comparing the two definitions of forests, note how rubber, oil palm plantations, and other areas are excluded from the second definition as well as lowland. Here, you see some form of greenwashing as well as green public relations. Greenwashing is used in the sense that Cambodia has all these policies, plans, programmes and important environmental issues that say it is addressing or has addressed, but avoids speaking about its economic land concessions and the inability to enforce its policies. Also, Cambodia blames its loss of forest cover on the civil war between the late 60 s and early 70 s, and the illegal felling of trees, agricultural shifts and land conversions for further use. 
The Cambodian government keeps issuing land concession licenses to foreign investors to grow its economy and make little effort to prevent further tree felling. For instance, these land conversions do not state that trees are cut down and forests burned to accommodate the expanding rubber business.

Cambodia stated that the REDD+ programme implementation will be in stages since they only joined in 2011. It divided its implementation into the preparation stage (2011-2015), for the collection of data and setting up of tools, personnel, and equipment for the programme, implementation stage from 2016 to 2020 and followed by a final stage of evaluation of results (Cambodia Ministry of Environment, 2018). It is however binding on Cambodia as with other countries that reports and reviews should be done in different ways. The first is the biennial update report in which Cambodia informs the committee at REDD+ on its national circumstances, challenges, capacity needs, etc. This report in turn is subjected to consultations and analysis, internationally. The second report is based on national communications which include the same areas as with the biennial updates but not subjected to any review process. These REDD+ reports are result-based attracting incentives based on implementation. The need to be paid for implementation allows countries to amplify their activities or tamper with reports to gain eligibility for payments. To scrutinise the process, the REDD+ board has stated that payments are made after technical assessments of submitted reports are finalised. These assessment reports are rarely done; only one report is available on Cambodia since 2002, almost a 16-year gap. And when it is done, it is done using the already existing workforce and systems. Here, with REDD+, we see a partnership with the United Nations that brings blue washing to play. Not only by the government but by corporations within the government who claim to respect the tenets of the Global Compact with their commitment letters being along the lines of supporting the 10 principles of the Global Compact with respect for the environment, labor, human rights, anti-corruption, etc. Except that there is constant policing, monitoring, evaluation, and observations by the UN within these countries, how is it to know if what is stated in reports and documents translate to reality on the ground? The Global Compact continues to face condemnation by environmental activists as many corporations under its umbrella have the worst environmental practices but get away with it because it is the 'UN'. 


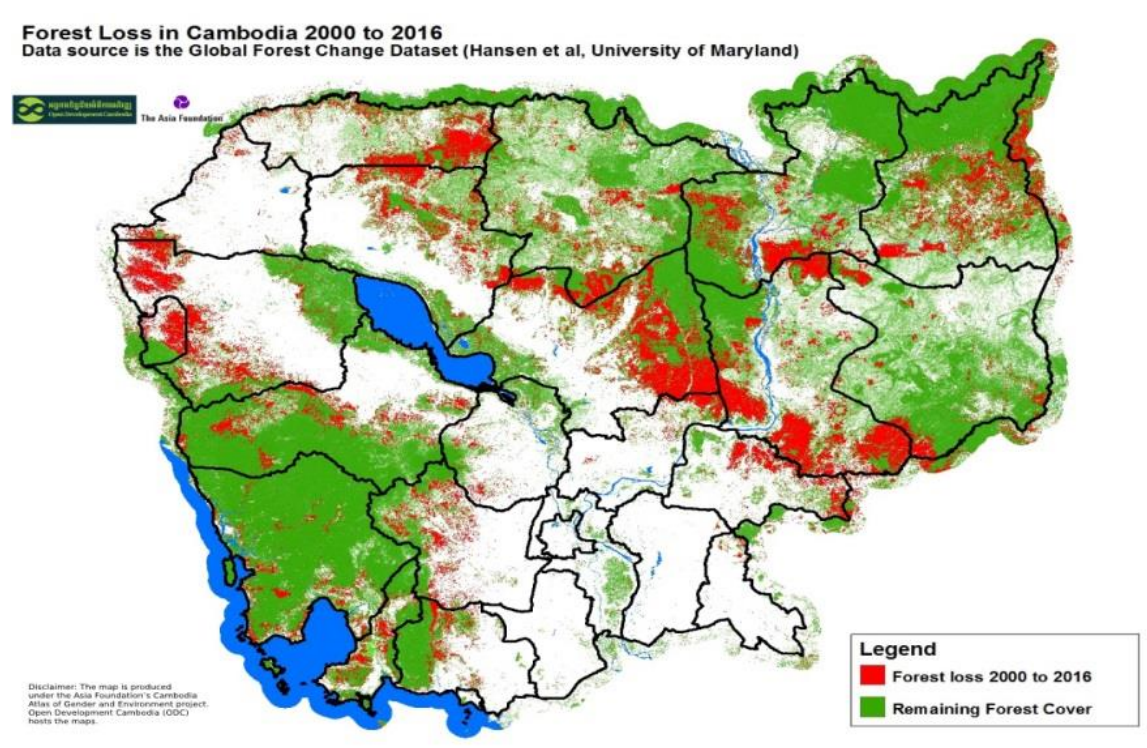

Figure 3: Forest Cover Loss (2000 - 2016)

(Source: Maps Catalog [n.d.].)

In 2017, NASA released images of deforestation in Cambodia. It also stated in its findings like other institutions that Cambodia had lost about 1.59 million hectares of tree cover in 14 years since the year 2000 which had led to the disappearance of tigers and the lasting adverse effects on the wildlife habitat in the country. Also, NASA stated that rubber plantations were sporadically replacing these forests as a result of Cambodia's concession deals with timber and rubber companies. These land areas were legally allotted to agricultural companies for agricultural development, however, according to the Global Forest Watch (2015), Cambodia's loss of 1.59 million hectares of tree cover resulted in the emission of about 533 million metric tons of Carbon in 14 years between the year 2000 and 2014. This has been a large contributor to global warming and the endangering of human, plant, and animal life, a report that also correlates with the concerns of a science advocacy nongovernmental organisation called the Union of Concerned Scientists (Erickson-Davis, 2017). 


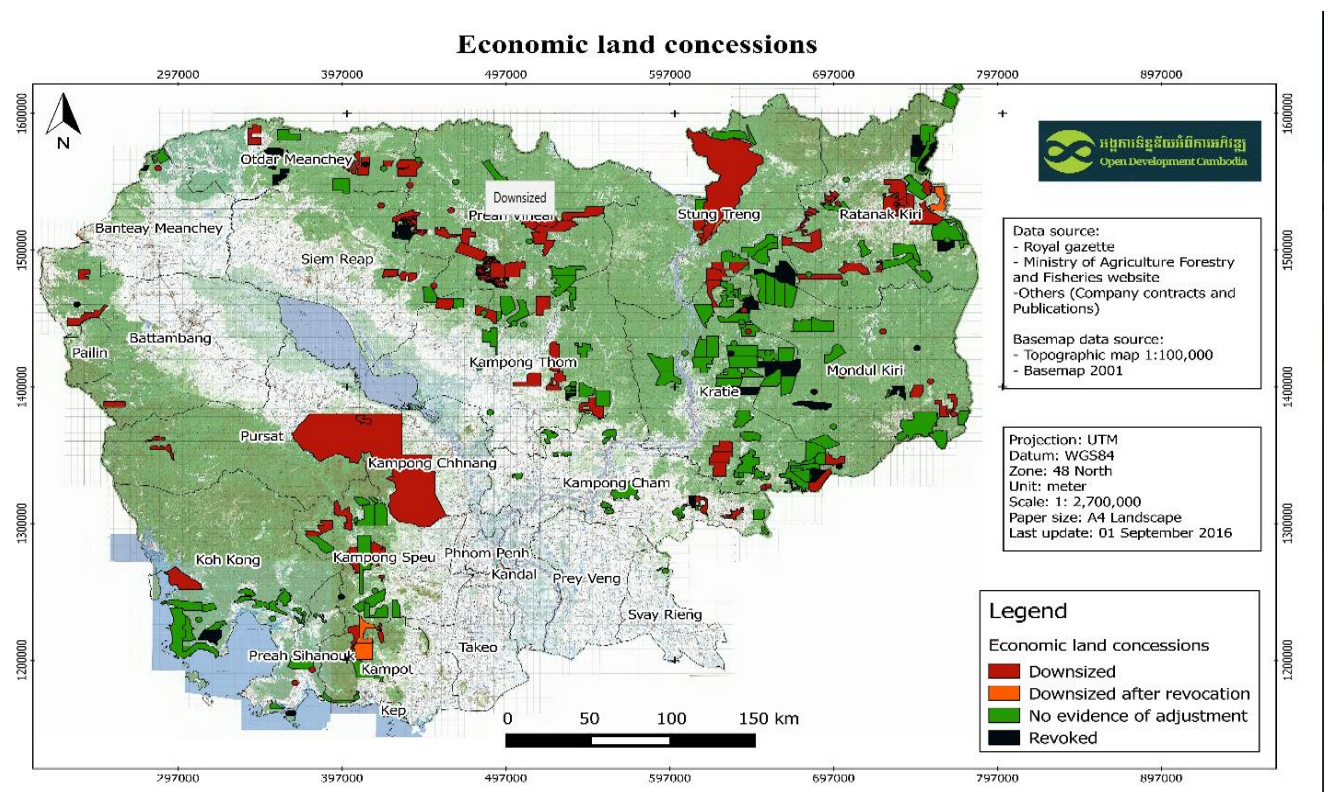

Figure 4: Economic Land Concessions since 2001 (Source: Maps Catalog [n.d.].)

Cambodia is said to be home to some of the oldest and diverse forests in South East Asia (Janssens, 2018). According to reports, Cambodia has handed down to corporations such as the Economic License Concessions for agricultural developments for long periods. Due to these companies not adhering to transparency measures of their activities, Cambodia after discovering that $90 \%$ of logged timbers are being sold on the black market, imposed sanctions on tree felling and employed forest rangers to monitor activities as much as they can. But in practice, timber is being logged in thousands every day, instead of agricultural 'development' (Janssens, 2018). Only a couple of licenses have been revoked while the majority have no evidence of adjustment to Cambodian forest laws and regulations.

Despite all these dynamics, it is clear that Cambodia is a far cry from being eco-friendly; its forests are being felled at a frightening rate with officials and corporations benefiting from sales on the black market. Trees of great value and hard to come by are cut down and shipped for sale to other parts of the world including Europe (European Union Delegation to Cambodia, 2012). These practices are endangering wildlife and causing gas emissions in millions of metric tons. Environmental activists are reported to be targeted for carrying out investigations on illegal logging activities. The government also reportedly shutdown Cambodia Daily, a newspaper company, for reporting extensively on 
these practices within the country. The report also stated that most of the corporations authorised by the government for agricultural development are interested in Rosewood, a rare type of tree whose wood is best for furniture and flooring. Rosewood is projected to go into extinction by 2026 since the last batch of trees of this kind in the region is in Cambodia (Janssens, 2018). With this rate of deforestation, I doubt that Cambodia is concerned for its rare forests and ecosystem. There are hundreds of illegal businesses as regards to its forests but yet, it thrives without being questioned. You would imagine that instead of formulating supposed policies, the Cambodian government will play a more active or pro-active role in stamping out the practice by using force, law enforcement as well as charging offenders to court and sentencing them, wherever possible. But it continues to hand out lands even in reserved areas to the highest bidders and licenses that should take months to process after environmental and safety checks have been conducted and done in weeks (European Union Delegation to Cambodia, 2017).

\section{Cambodia's Position on Greenhouse Gas Emissions}

Concerning the reduction of greenhouse gas emissions, we see a strong commitment by Cambodia to climate change, most recently in 2015 with the submission of its Intended Nationally Determined Contribution (INDC) to the UNFCCC ahead of the Paris Agreement that comes into effect in 2020 (Ritchie \& Roser, 2017). This is a new climate change agreement by most countries to commit to preventing a further increase of global temperatures above two degrees by reducing their greenhouse gas emissions. These countries are not expected to renegade on their commitments but to continue to improve on it.

In previous research, greenhouse gases emitted into the atmosphere are a major contributor to climate change in Cambodia. These gases such as Methane are released as a result of bad agricultural practices and the decomposition of solid waste on land (Denney, 2016). However, there are not enough trees and plants to take in the carbon dioxide that humans and animals breathe out due to timber logging, bush burning, burning of fossil fuels such as coal and natural gas, etc. which are all sources of carbon emissions. Nitrous oxide, another GHG released during agricultural and industrial activities and often used as a recreational drug, has been banned in some countries. The last category of gases is called fluorinated gases, also known as 'global warming potential gases' because they are emitted as a result of technological advancements and industrial processes. These fluorinated gases when emitted are stored in the atmosphere for years. Some examples of these gases are sulfur hexafluoride, nitrogen trifluoride, hydrofluorocarbons and perfluorocarbons found in deep freezers, refrigerators, 
aerosol containers, air conditioners, heaters, fans, etc. (Greenhouse Gas Emissions, 2019).

\section{Practices of Greenhouse Gas Emissions in Cambodia}

It has already been established in previous subchapters on waste management and pollution and deforestation in Cambodia that these practices are the major contributors to high emissions of GHGs in the atmosphere. Cambodia also has large deposits of mineral and natural resources such as gold, silver, iron ore, lead, tin, bauxite, copper and so on and as a result of recent economic concessions, mining and extractive industries are carrying out their activities. The rate of consumption of fossil fuels such as coal and wood by households continues to increase as many households depend on the cheapest nonrenewable energy sources for domestic use. Also, the majority of the Cambodian population live in rural areas and work as farmers, fishermen, and rear animals for domestic and commercial consumption (Cambodia Ministry of Mines and Energy, 2016).

Table 1: Cambodia's Total CO2 and GHG Emissions

\begin{tabular}{|l|l|l|l|l|l|l|l|l|}
\hline YEAR & 1990 & 2000 & 2005 & 2010 & 2012 & 2014 & 2015 & 2016 \\
\hline EMISSIO & 982.6 & 1981.7 & 2669.9 & 4146.8 & 4660.7 & 5674.9 & 6033.7 & 6496.9 \\
NS & 2 & 1 & 2 & 2 & 8 & 5 & 2 & 6 \\
\hline
\end{tabular}

Source: European Union Delegation to Cambodia (2017).

The above table reveals the continual increase of $\mathrm{CO} 2$ and greenhouse gas emissions in Cambodia with the most recent year as 6496.96 kilotons. Compared to the tremendous increase between 2005 and 2010, emissions are still increasing but not as much as in previous years. Figure 5 below sheds more light on the sectors that are sources of emissions and gases that are mostly emitted. 
Fossil CO2 emissions by sector (EDGARv4.3.2_FT2016 dataset)

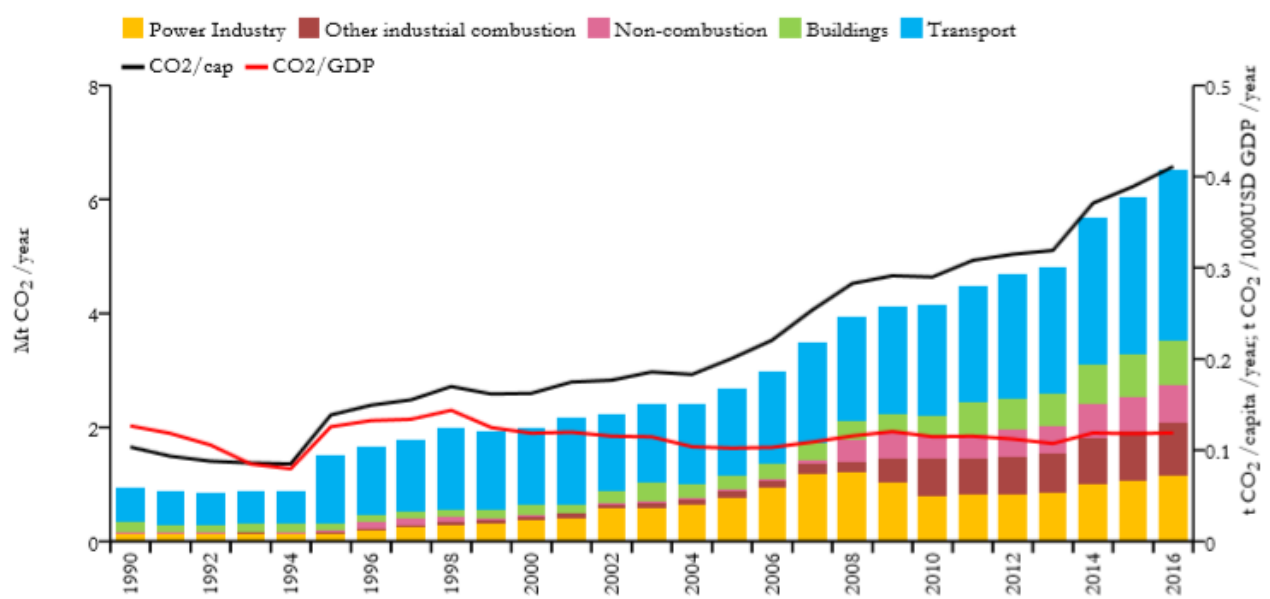

Figure 5: Fossil CO2 emissions by sector from 1990 to 2016 (Source: European Union Delegation to Cambodia (2017).

The figure above shows the emissions of carbon dioxide by various sectors in Cambodia. Cambodia's transport sector emits the highest amount of Carbon Dioxide because the public transportation system is made up of carts, cars, and motorcycles referred to as 'tuk-tuk' that depend on fossil fuels to run. These public means of transportation are also utilised in several cities and towns in developing countries across Asia, Latin America and Africa. The Cambodia capital, Phnom Penh alone has experienced a growth of motorcycles from about 100,000 to about a million in the last ten years. The motorcycle taxis called 'motodup' is powered by fossil fuels and the fastest, yet the most dangerous means to get around. There are also 'cyclos' which are much slower and powered by pushing or pulling. In 2014, the Cambodian government due to the problem of traffic congestion, reintroduced its public buses to solve the gridlock problems which initially failed in 2001 because commuters would rather have a motodup drop them at their doorsteps than ride in a bus that would require them to walk a few minutes with luggage (Connor, 2017).

According to the Asian Development Bank's report on Cambodia's transport sector, it is said to be unsafe and riddled with unsustainability and draws it back on achieving its Millennium Development Goals and Sustainable Development Goals. These issues in summary are reported to be caused by inconsistent and incomplete transport policies (Asian Development Bank, 2011). The bank also states in its sector assessment that Cambodia's transport sector is yet to reflect any climate change adaptability. In the second phase of its Rectangular Strategy that I have discussed in my previous research, the transport 
sector's role in achieving green growth is clearly defined. Cambodia states that further reconstruction and rehabilitation are needed, although some progress has already been made. Also to mention, Methane is topmost on the list of greenhouse gases emitted by Cambodia (ASEAN Development Bank, 2011). This gas is potent and emitted as a result of landfills, oil and gas production and distribution, fermentation, mining, and so on, all of which are common to Cambodia.

Note that Cambodia aims to go from the least developed country to a middle-income country from 2025 to 2030 according to its INDC statement through industrialisation, economic diversification, and also the development of infrastructure. Cambodia still claims to have over 57\% forest cover and is seeking to improve on it up to about $60 \%$ by 2030 (United Nations Framework Convention on Climate Change [UNFCCC], n.d.). Cambodia also proposes mitigation efforts between 2020 and 2030 on the condition that it receives support from the international community.

\section{Conclusion}

Examining Cambodia as a least developed country against the concepts of greenwashing, blue washing and green public relations, it is clear that its international stand is not sufficient to measure the authenticity of its commitment to combatting climate change. In depth investigation into its national practices, policies, and mitigation efforts to see whether they are in sync is important. In this article, Cambodia, one of the least developed countries that adopted the UNFCCC, the Kyoto Protocol, REDD+, the Paris Agreement, and also actively participates at important climate change summits like Rio+20 and pledges support to pressing climate and environmental issues. In Cambodia's case, there is a struggle between poverty reduction and building its foreign reserves through the allocation of economic land concessions to companies for rubber plantations, timber logging, and the growing mining sector. Due to the recent discovery of silver and other mineral resources by an Australian mining corporation, Cambodia is in a dilemma between economic growth and mitigating the impacts of climate change by paying attention to the environment.

Cambodia is one of the most vulnerable countries to the impacts of climate change and has in recent times, begun making some effort with the help of several organisations in mitigating the climatic and environmental challenges that it faces as a nation. However, Cambodia is projected to experience more deadly impacts of climate change even if it actively reduces the triggers of its poor climatic conditions. The effects of climate change are inevitable not just in Cambodia but even in the world at large. 
Some inconsistencies exist in Cambodia's depictions of combating climate change. These actions are simply postponing doom's day with environmental practices such as landfills as a way of managing waste, shocking levels of deforestation all over the country, greenhouse gas emissions as a result of means of transportation, and other activities like burning fossil fuels for domestic use. I would also imagine that the mining and extraction sector will be fully exploited in a few years too. Also one of the challenges is that some data and information cannot be verified as they are in the Khmer language or not even accessible to the public.

Cambodia like most developing and emerging economies shows commitment to curbing climate change. However, its weak institutions have led to little or no progress in combating climate change. Newly established institutions often require time to develop to the capacity of implementing and enforcing its several policies and plans for the environment and climate.

Oftentimes, this is the reality in other countries like Colombia, Peru and South Africa, and even in developed nations like the United States, Canada, and China. There is a constant struggle between good intentions for the climate and the need for economic growth and development. It is the scenario of various actors and their interests, even if it means gradual destruction of natural resources.

\section{Acknowledgement}

This paper was presented at the International Association of Political Science Students (Europe 2019) Conference on the Paths to Climate Justice at Stockholm University in Sweden.

\section{References}

Asian Development Bank. (2011). Cambodia: Transport sector assessment, strategy, and road map. Mandaluyong City, Philippines. Retrieved from https://www.adb.org/sites/default/files/institutionaldocument/33102/files/cam-transport-assessment.pdf

Asia and the Pacific: Weekly regional humanitarian infographic. (2016, May 30). UN Office for the Coordination of Humanitarian Affairs. Retrieved from https://reliefweb.int/report/sri-lanka/asia-and-pacific-weekly-regionalhumanitarian-snapshot-24-30-may-2016

AZoCleantech. (2008). Greenwashing, a definition of what greenwashing is, examples of greenwashing and how to spot greenwashing. Retrieved from https://www.azocleantech.com/article.aspx?ArticleID=109

Borg, L. F. (2011). Climate change and human security in Cambodia. Cambodian 
Institute for Peace and Cooperation. Working Paper no. 46. Phnom Penh. Retrieved from http://www.cicp.org.kh/userfiles/file/Working\%20Paper/CICP\%20Worki ng\%20Paper\%20No\%2046_Climate\%20Change\%20and\%20Human\%20Se curity\%20in\%20Cambodia.pdf

Bowen, F. (2014). After greenwashing: Symbolic corporate environmentalism and society. Cambridge: Cambridge University Press.

Cambodia Ministry of Environment. (2018) Cambodia forest cover 2016. Retrieved from

https://redd.unfccc.int/uploads/54_3_cambodia_forest_cover_resource_2 016_english.pdf

Cambodia Ministry of Mines and Energy. (2016). Environment health and society. Retrieved from http://www.mme.gov.kh/en/article/282/Environment-Health-andSociety.html

Chan, S. (2018, January 30). Three Cambodian cities named among the cleanest in ASEAN. Khmer Times. Retrieved from https://www.khmertimeskh.com/50105168/three-cambodian-citiesnamed-among-the-cleanest-in-asean/

Connor, L. (2017, June 25). What will become of Cambodia's endangered tuk-tuk drivers? South China Morning Post. Retrieved from https:/www.scmp.com/week-asia/society/article/2097978/what-willbecome-cambodias-endangered-tuk-tuk-drivers

Cornell, A. (2010). Small actor, big opinion: Least developed countries participation in climate change networks. Procedia-Social and Behavioral Sciences, 4, 59-70.

Data Center: International Indicators. (n.d.). Retrieved June 25, 2020, from https://www.prb.org/international/geography/cambodia

Denney, L. (2016, May). Reforming solid waste in Phnom Penh. The Asia Foundation. Retrieved from https://asiafoundation.org/publication/reforming-solid-wastemanagement-phnom-penh/ or https://asiafoundation.org/wpcontent/uploads/2016/06/Working-Politically-and-Flexibly-to-ReformSolid-Waste-Management-in-Phnom-Penh.pdf

Environmental Performance Index. (2018a) Country profile Cambodia. Yale University. Retrieved from

https://epi.envirocenter.yale.edu/sites/default/files/2018-khm.pdf

Environmental Performance Index. (2018b). Results. Yale University. Retrieved 
from at https://epi.envirocenter.yale.edu/epi-topline

Erickson-Davis, M. (2017, January 13). NASA releases images of dramatic deforestation in Cambodia. Mongabay. Retrieved from https://news.mongabay.com/2017/01/nasa-releases-images-of-dramaticcambodia-deforestation/

European Commission: Disaster Risk Management Knowledge Centre. (2018). Index for Risk Management: Country Profile on Cambodia. Retrieved from https://drmkc.jrc.ec.europa.eu/inform-index/Countries/CountryProfile-Map

European Union Delegation to Cambodia. (2012). Cambodia: Country environmental profile. Emission Database for Global Atmospheric Research. Retrieved from http://eeas.europa.eu/archives/delegations/cambodia/documents/publicat ions/country_env_profile_cam_april_2012_en.pdf

European Union Delegation to Cambodia. (2017). Cambodia Emissions Database for Global Atmospheric Research Cambodia. European External Action Service. $\quad$ Retrieved from http://edgar.jrc.ec.europa.eu/booklet2017/countries/KHM.pdf

Fingas, J. (2017, October 17). Greenpeace blasts Amazon over poor environmental practices. Engadget. Retrieved from https://www.engadget.com/2017/10/17/greenpeace-blasts-amazon-overpoor-environmental-practices/

Forbes, L. C., \& Jermier, J. (2012). The new corporate environmentalism. In P Bansal, \& A. Hoffman (Eds.), The Oxford handbook of business and the natural environment (pp. 556-571). Oxford: Oxford University Press.

General Secretariat of the National Council for Sustainable Development (2014). DCC Organigram. Department of Climate Change. Retrieved from http://www.camclimate.org.kh/en/photo-galleries/category/31-2012youth-drawing-competition.html

Global Forest Watch. (2015). Tree plantations. Retrieved from https://www.globalforestwatch.org/Greenhouse Gas (GHG) Emissions. (2019, August 08). Retrieved September 12, 2018, from https://www.epa.gov/ghgemissions

Greenwash Fact Sheet. (2001, March 22). Corpwatch. Retrieved from https://corpwatch.org/article/greenwash-fact-sheet

Huq, S., Reid, H., Konate, M., Rahman, A., Sokona, Y., \& Crick, F. (2004). Mainstreaming adaptation to climate change in least developed countries (LDCs). Climate Policy, 4(1), 25-43.

Janssens, K. (2018, March 5). Corruption fueling deforestation in Cambodia. DW. 
Retrieved from https://www.dw.com/en/corruption-fuelingdeforestation-in-cambodia/a-42674051

Käkönen, M., Lebel, L., Karhunmaa, K., Dany, V., \& Try, T. (2014, September). Rendering climate change governable in the least-developed countries: Policy narratives and expert technologies in Cambodia. Forum for Development Studies, 41(3), 351-376.

Lawrence, D., \& Vandecar, K. (2015). Effects of tropical deforestation on climate and agriculture. Nature Climate Change, 5(1), 27-36.

Lilleør, H. B., \& Van den Broeck, K. (2011). Economic drivers of migration and climate change in LDCs. Global Environmental Change, 21, S70-S81.

Maps Catalog: 2008-2015 (n.d.). Open Development Cambodia. Retrieved from https://opendevelopmentcambodia.net/layers/page/2/\#

Matussek, K., \& Behrmann, E. (2018, September 12). VW can't escape the diesel scandal fall out. Bloomberg. Retrieved from https://www.bloomberg.com/news/articles/2018-09-12/vw-can-t-escapethe-diesel-scandal-fallout

Moutinho, P., \& Schwartzman, S. (2005). Tropical deforestation and climate change. Belem: Amazon Institute for Environmental Research.

National Forest Monitoring of Cambodia. (2015). REDD+ Cambodia. Retrieved from https://redd.unfccc.int/uploads/54_1_cambodia_nfms_sept_17.pdf

Our Mission: United Nations Global Compact. (2000). Retrieved June 25, 2020, from https://www.unglobalcompact.org/what-is-gc/mission

Overland, I., Azlan, L., Charadine, P., Chongkittavorn, K., Eksuriya, C., Estrada, E. S., Husain, S. A., Jaabi, A., Lemphers, N., Mohd. Yatid, M., Nguyuen, H. T., Parcon, R. J. M. L. C., Pek, S., Perkasa, V., Selamat, F., Soborliboun, C., Sothirak, P., Suchindah, A., Thein, K. N. N., Tin, D. K. T., Vakulchuk, R., Wijaya, A., \& Zainul, H. (2017) Impact of climate change on ASEAN international affairs: Risk and opportunity multiplier. n.p.: Norwegian Institute of International Affairs and Myanmar Institute of International and Strategic Studies. Retrieved from https://www.researchgate.net/publication/320622312_Impact_of_Climat_ Change_on_ASEAN_International_Affairs_Risk_and_Opportunity_Multi plier

Petersen, R., Sizer, N., Hansen, M., Potapov, P., \& Thau, D. (2018, September 26). Satellites Uncover 5 Surprising Hotspots for Tree Cover Loss. Retrieved May 25, 2018, from https://www.wri.org/blog/2015/09/satellites-uncover5-surprising-hotspots-tree-cover-loss

Pollution and Waste. (2016, January 5). Open Development Cambodia. Retrieved from https://opendevelopmentcambodia.net/topics/pollution-and-waste/ 
Policies and Plans. (2013). Retrieved from https://ncsd.moe.gov.kh/ncsd/policiesand-plans

Rampton, S. (2002, January 24). From greenwash to bluewash. The Centre for Media and Democracy PR Watch. Retrieved from https://www.prwatch.org/spin/2002/01/999/greenwash-bluewash

Rathana, K. (2009, May). Solid waste management in Cambodia. Cambodian Institute for Cooperation and Peace. Working Paper No. 27. Phnom Penh. Retrieved from http://www.cicp.org.kh/userfiles/file/Working\%20Paper/CICP\%20Worki ng\%20Paper\%2027\%20solid\%20waste\%20management_Edited.pdf

REDD+ Cambodia submissions. (n.d.). United Nations Framework Convention on Climate Change. Retrieved from https://redd.unfccc.int/submissions.html?country=khm

Rinkesh. (n.d.). What is greenwashing? (Web blog post). Conserve Energy Future. Retrieved from https://www.conserve-energy-future.com/topgreenwashing-examples.php

Ritchie, H., \& Roser, M. (2017, May). CO2 and greenhouse gas emissions. Our World in Data. Retrieved from https://ourworldindata.org/co2-and-othergreenhouse-gas-emissions

Sassoon, A. M., \& Channyda, C. (2018, March 16). Phnom Penh smothered in smelly, dangerous haze as landfill fire continues burning. The Phnom Penh Post. Retrieved from https://www.phnompenhpost.com/national/phnompenh-smothered-smelly-dangerous-haze-landfill-fire-continues-burning

Schott, B (2010). Blue washing. The New York Times. Retrieved from https://schott.blogs.nytimes.com/2010/02/04/bluewashing/

Shukla, J., Nobre, C., \& Sellers, P. (1990). Amazon deforestation and climate change. Science, 247(4948), 1322-1325.

Smith, O. (2017, April 22). Mapped: The world's most eco-friendly countries where does the UK rank? The Telegraph. Retrieved from https://www.telegraph.co.uk/travel/maps-and-graphics/most-and-leastenvironmentally-friendly-countries/

Solid Waste Management App. (2018, March 22). UNDP Cambodia. Retrieved from

http://www.kh.undp.org/content/cambodia/en/home/ourperspective/soli d-waste-management-app.html

Sopheap, E., Inatsu, Y., Thavrak, H., \& Borarin, B. (2016). Isolation, characterisation, and bio-control activities of Bacillus subtilis from in fermented soybean in Cambodia. Final Report of NFRI-UNU-KIRIN Fellowship Program (2015-2016), 1-34. 
The problem with landfill. (2013, June 16). Environment Victoria. Retrieved from https://environmentvictoria.org.au/resource/problem-landfill/

Tinker, P. B., Ingram, J. S., \& Struwe, S. (1996). Effects of slash-and-burn agriculture and deforestation on climate change. Agriculture, Ecosystems $\mathcal{E}$ Environment, 58(1), 13-22.

Tola, S. (2018, February 16). rating cambodia's cleanliness. Khmer Times. Retrieved from https://www.khmertimeskh.com/50108741/rating-cambodiascleanliness/

United Nations Global Compact. (n.d.). Communication on progress: Ezecom (2015-2017). Retrieved from https://www.unglobalcompact.org/participation/report/cop/create-andsubmit/active/357591

United Nations Framework Convention on Climate Change (UNFCCC) (n.d). Gas emissions data by party: Cambodia. Retrieved from http://di.unfccc.int/detailed_data_by_party

Zumach, A. (2011). "Blue wash" instead of human rights. DW. Retrieved from https://www.dw.com/en/blue-wash-instead-of-human-rights/a-15108305

Date Received: 5 August 2019 Date of Acceptance: 1 June 2020 